\title{
Engineering Geological Assessment of Diversion Tunnel of Bakhtiari Damsite (Biggest Two-Arch Concrete Dam in Southern Iran)
}

\author{
R. Ajalloeian, ${ }^{1}$ A. R. Samadi Soofi, ${ }^{2}$ and M. Salavati ${ }^{3}$ \\ ${ }^{1}$ Department of Geology, The University of Isfahan, Isfahan 81746-73441, Iran \\ ${ }^{2}$ Department of Geology, Science \& Research Branch of Tehran, Islamic Azad University, Tehran 14478-93855, Iran \\ ${ }^{3}$ Department of Geology, Lahijan Branch, Islamic Azad University, Lahijan 44169-39515, Iran
}

Correspondence should be addressed to A. R. Samadi Soofi, alirezasamadisofi@yahoo.com

Received 16 March 2012; Revised 16 August 2012; Accepted 16 August 2012

Academic Editor: Atle Nesje

Copyright (C) 2012 R. Ajalloeian et al. This is an open access article distributed under the Creative Commons Attribution License, which permits unrestricted use, distribution, and reproduction in any medium, provided the original work is properly cited.

\begin{abstract}
Bakhtiari dam is located on the Bakhtiari river, $120 \mathrm{~km}$ away from the north of the Andimeshk city. Upper diversion tunnel of this dam with large cross section ( $13.7 \mathrm{~m}$ excavation diameter) and more than $1 \mathrm{~km}$ length is a huge construction. The tunnel is placed in the Sarvak formation carbonate rocks of Bangestan group which passes through seven different geological zones with various specifications (SV1, SV2, SV3, SV4, SV5, SV6, and SV7). Joint studies show two main discontinuit including bedding and a main group of joint (J1) together with random joints (faults and fractures). Most of discontinuities have been filled mainly by calcite or calcite and clay. Data deduced from testing and analysis shows good-to-excellent RQD classes with 75 to 90 values. Based on RMR and $Q$ methods, generally rock masses have good to very good quality with 61 to 95 values for RMR and 10 to 35 values for $Q$. Based on conducted stability analysis, suitable supports were suggested for tunnel by RMR and $Q$ methods. As a result, it can be concluded that all units have a good stability. Therefore, systematic rock bolting with 40-50 mm unreinforced shotcrete has been proposed for some special place. For rock support, according to RMR method, $3 \mathrm{~m}$ rock bolts in crown, $2.5 \mathrm{~m}$ spacing and with $50 \mathrm{~mm}$ shotcrete in crown has been proposed also $3 \mathrm{~m}$ rock bolts, based on $Q$ method, 2.3-2.4 m spacing with systematic Bolting without shotcrete or $40 \mathrm{~mm}$ unreinforced shotcrete in some units, has been proposed. According to RMR method, for SV5 zone with very good and excellent quality, local 33 bolting without shotcrete and $3 \mathrm{~m}$ rock bolts, $3 \mathrm{~m}$ spacing and spot bolting according to $Q$ method has been proposed.
\end{abstract}

\section{Introduction}

In recent years, following the increasing need to create spaces underground with larger scale and in greater depth in poor areas (such as underwater), identifying more and more of the earth is evident. In relation to construction of dams, geological survey is the most important parts of studies which can be useful and valuable information about the design of underground spaces offer [2]. Feasibility of these constructions in natural materials, such as rock and soil, causes the geological conditions to play a major role in their stability [3]. Dams are considered as one of the most important civil structures. Arch dams with high stresses on their foundation highlight the role of rock mechanics studies. It should be noted that many geological data cannot be directly applied in the design of underground constructions, so in recent years; many efforts have been made for geotechnical classification [4]. In order to design dam and its appurtenant structures and assure about their stability, it is required to evaluate the engineering behavior of their surrounding rock masses. In this regard, physical and mechanical properties of the rock masses should be estimated based on engineering geological and rock mechanics field and laboratory investigations.

Rock mass characterization is normally carried out through the application of empirical classification systems, which use a set of geotechnical data and provide an overall description of the rock properties [6]. Moreover, they provide other important information like support needs, stand-up time, and geotechnical parameter among others 


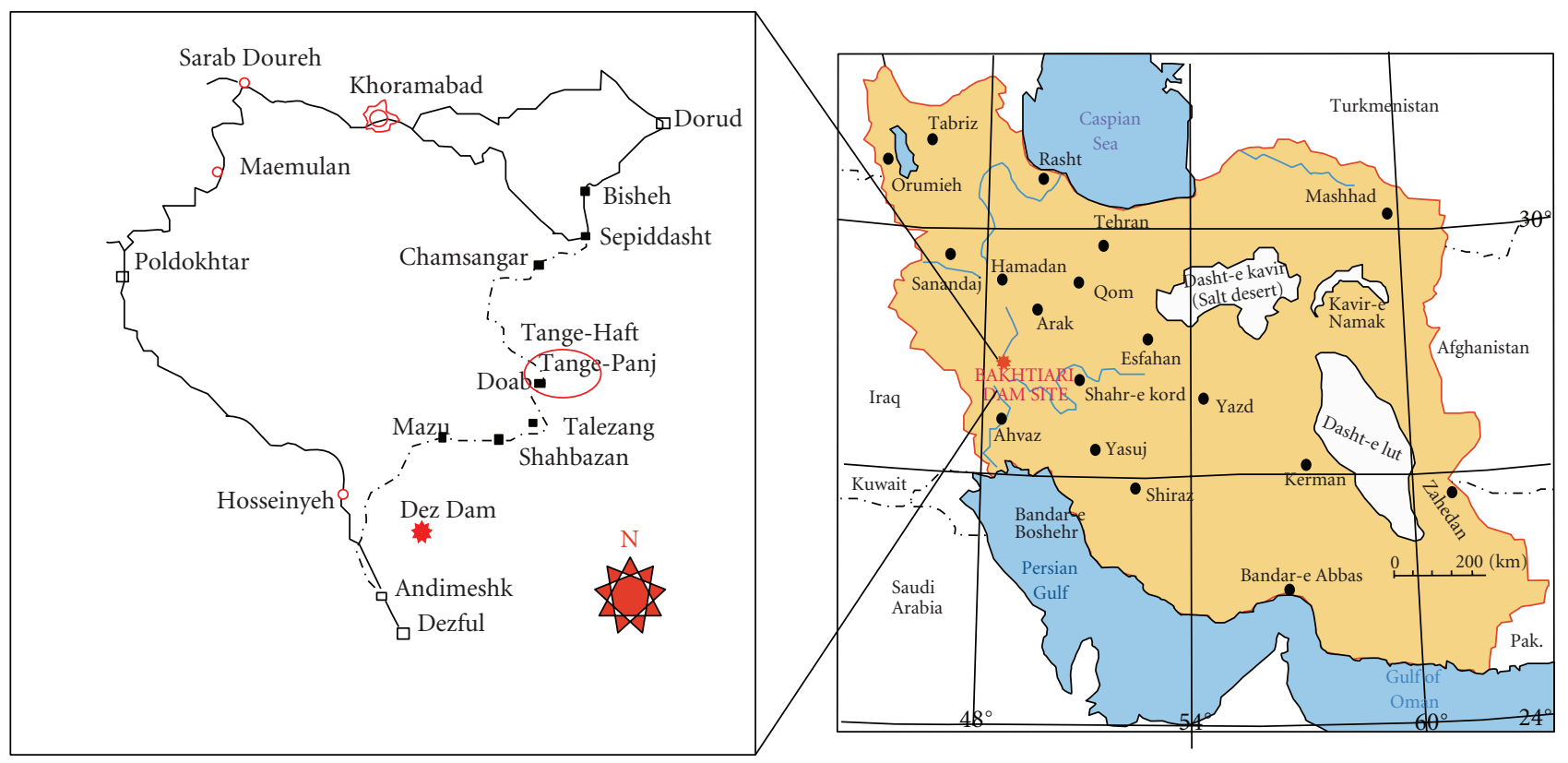

\footnotetext{
- Village $\sim$ Asphalted road

口 Town .... Railway

(0) Province center
}

FIGURE 1: Location of the project area on Iran map and access roads to the project area.

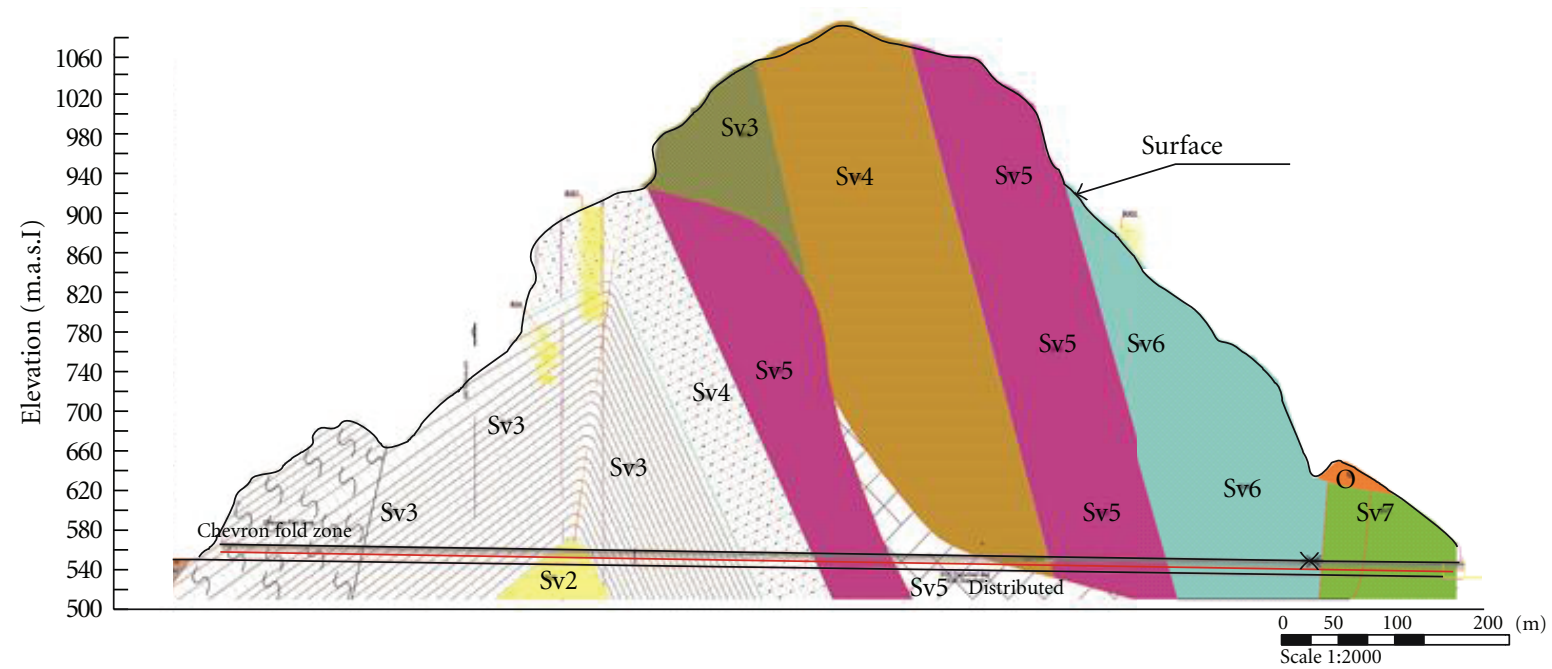

FIgURE 2: Geological longitudinal section of the upper water diversion tunnel.

[7]. Two of the most used classification systems are the RMR - Rock Mass Rating and the Q-system [7]. RMR and Q systems have evolved over time to better reflect the perceived influence of various rock-mass factors on excavation stability [8]. Stability and support design for water diversion tunnel of Bakhtiari dam, based on five boreholes at the upstream and downstream cofferdams and four boreholes along the diversion tunnels path, has been investigated in previous studies [9]. This paper presents the results of rock mechanics studies of the upper diversion tunnels at Bakhtiari dam 


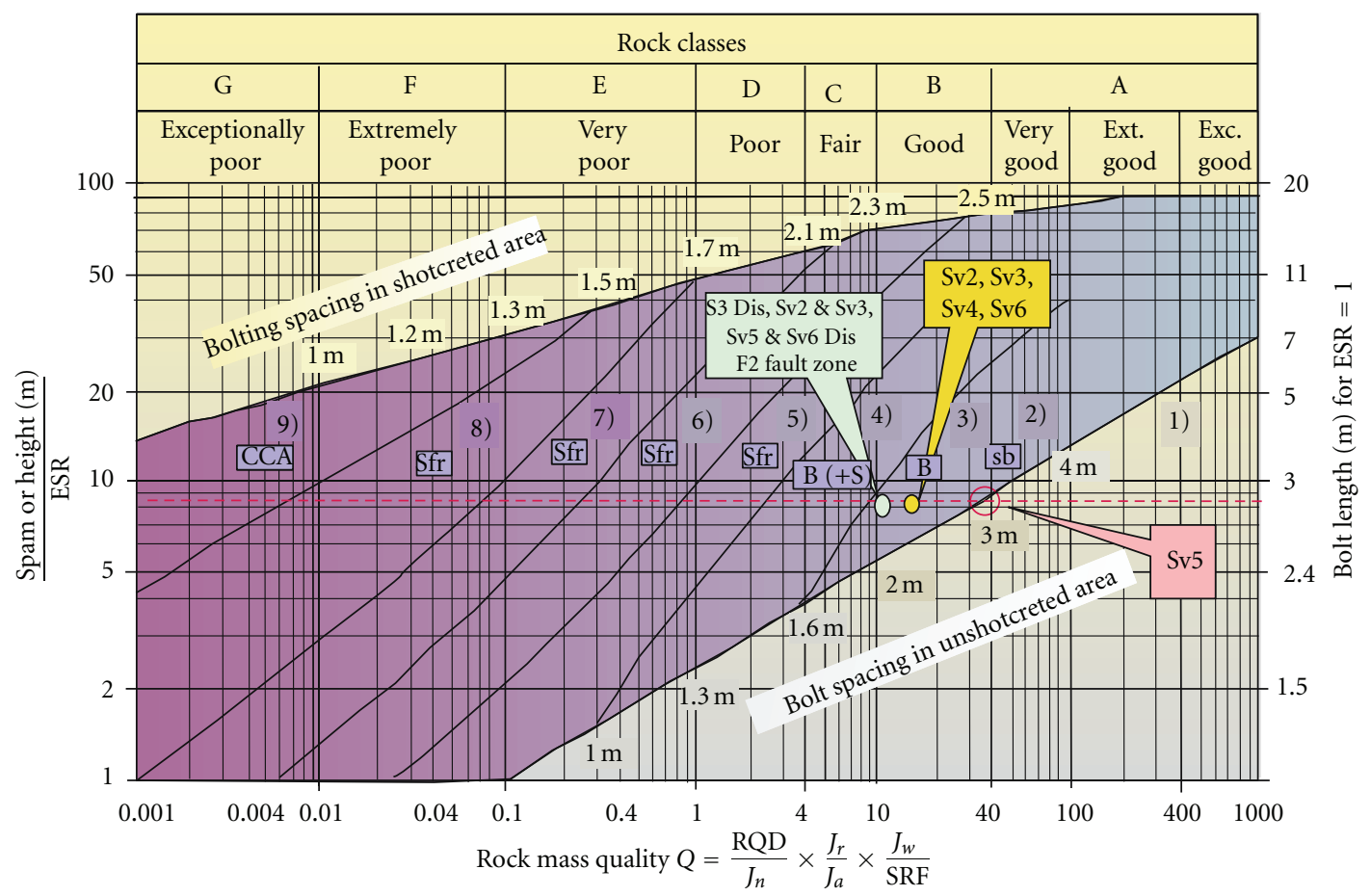

Reinforcement categories:
1) Unsupported
2) Spot bolting, sb
5) Fibre reinforced shotcrete and bolting, $5-9 \mathrm{~cm}, \mathrm{Sfr}+\mathrm{B}$
3) Systematic bolting, B
6) Fibre reinforced shotcrete and bolting, $9-12 \mathrm{~cm}, \mathrm{Sfr}+\mathrm{B}$
4) Systematic bolting,
(and unreinforced shotcrete, $4-10 \mathrm{~cm}), \mathrm{B}(+\mathrm{S})$
7) Fibre reinforced shotcrete and bolting, $12-15 \mathrm{~cm}$, $\mathrm{Sfr}+\mathrm{B}$
8) Fibre reinforced shotcrete $>15 \mathrm{~cm}$,
reinforced ribs of shotcrete and bolting, Sfr+RRS+B
9) Cast concrete lining, CCA

E) Energy absorption in fibre reinforced shotcrete at $25 \mathrm{~mm}$ bending during plate testing

FIGURE 3: Estimation of reinforcement categories for the upper diversion tunnel based on tunneling quality index $(Q)$, [10].

TABLE 1: Name, symbol, and other details of formations that are available in the dam water diversion tunnels.

\begin{tabular}{ll}
\hline $\begin{array}{l}\text { Formation length in the upper } \\
\text { tunnel during excavation }(\mathrm{m})\end{array}$ & Formation characteristics \\
\hline 78 & $\begin{array}{l}\text { Marly limestone (gray color if fresh or moderately weathered) with intercalations of } \\
\text { marls and shales. Thickness of marly limestone layers varies from } 0.15 \text { to } 0.4 \mathrm{~m} \text { and } \\
\text { shale layers change from } 3 \text { to } 15 \mathrm{~cm} .\end{array}$ \\
\hline 233 & $\begin{array}{l}\text { Alternating layers of dark gray marly limestone and siliceous limestone. Limestone } \\
\text { layers have thickness between } 10 \text { to } 30 \mathrm{~cm} \text {, and siliceous limestone layers are } 5 \text { to } \\
20 \text { cm thick. }\end{array}$ \\
\hline 134 & $\begin{array}{l}\text { Is similar to part SV3 with a large number of discontinuities that leads to changes in } \\
\text { some parameters. }\end{array}$ \\
\hline 88 & $\begin{array}{l}\text { Medium to thick layered limestone of dark grey color, if fresh, and grey color if } \\
\text { moderately weathered with small nodules of siliceous limestone including some } \\
\text { chert and very thin intercalation of marl layers separate the limestone beds. }\end{array}$ \\
\hline 183 & $\begin{array}{l}\text { Thick to very thick gray nodular limestone with silica nodules and rarely made of } \\
\text { chert }\end{array}$ \\
\hline 105 & Medium to thickest dark gray limestone and marly limestone with intercalations. \\
\hline & $\begin{array}{l}\text { Thin to medium thick of dark gray to black limestone and marly limestone layers } \\
\text { (0.2 to } 0.4 \text { m) with thin marly intercalations. Thicknesses of these layers vary from } \\
20 \text { to } 40 \text { cm. }\end{array}$ \\
\hline
\end{tabular}


TABLE 2: Dip and dip direction of the rock masses discontinuities.

\begin{tabular}{lc}
\hline Dip direction/dip & Discontinuity type \\
\hline $200 / 85$ & Bedding \\
$315 / 45$ & J1 joint set \\
Variable & Random joint set \\
\hline
\end{tabular}

site based on $Q$ and RMR indices during excavation and construction and finally rock-support design have been proposed for them.

\section{Methodology}

In this research, according to a detailed study during drilling, engineering geological properties and stability for upper water diversion tunnel of the Bakhtiari Dam has been investigated and rock support design has been proposed.

For this purpose, lithological properties of rocks along the tunnel were evaluated during drilling with the manual sampling. During drilling, properties of discontinuity (such as dip/dip direction, roughness, Infilling, and spacing) in the rocks were studied. Series of data required for the investigation have resulted from testing and analysis of the excavated. These data indicate physical and mechanical properties of the seven various rock zones, including joint sets and discontinuities types with its properties. Based on these data, the values of RQD, RMR, and $Q$ and class of all the seven zone rocks were determined. Finally, Stability analysis has been conducted, and appropriate supports were suggested for tunnel by RMR and $Q$ methods.

\section{Discussion}

3.1. Geological Setting. Bakhtiari dam as the world's tallest concrete dam, is located in lower part of Bakhtiari river in Lurestan province and in southwest Iran, in southwestern of Zagros Mountains and in regional with $48^{\circ}, 46^{\prime}, 50^{\prime \prime}$ east length and $41^{\circ}, 57^{\prime}, 32^{\prime \prime}$ north latitude [11] (Figure 1). Deviation system of Bakhtiari dam includes two tunnels, namely upper and lower tunnels. The diameter of circular cross-section of the upper tunnel is $13.7 \mathrm{~m}$, and the length of this tunnel is $1181 \mathrm{~m}$ [11].

According to the interpretation of surface geology and data from drilling and exploration boreholes, damsite and its surrounding consists of folded carbonate sedimentary rocks which belong to Sarvak formation from Bangestan group. Rock type in diversion dam system in the Bakhtiyari damsite is mainly composed of carbonate deposits from Sarvak formations [12].

The Sarvak formation is divided into 7 units from SV1 (oldest) to SV7 (youngest) [13]. In Figure 2, longitudinal geological section of upper diversion tunnel has been shown. Table 1 illustrates the above mentioned units in detail. It is necessary to mention that the SV1 unit is not exposed in this area and hidden under the SV2 unit.
Structurally, two anticline (Giriveh and Siah Kuh anticline) and three faults (F1, F2, and F3 fault) are seen in the studied area.

(i) F1 fault caused the chevron fold zone and thus increased the amount of $\mathrm{d}$ discontinuities in the tunnel inlet portal.

(ii) F3 fault splits into two branches and crosses the middle part of the diversion tunnels.

(iii) F2 fault affects the end part of the tunnels.

3.2. Discontinuities System. The framework of all rock mechanics analysis is based on geological data [14]. These data help to identify the types of rocks, rock-mass characteristics and structural discontinuity [15]. In order to identify and determine the quality and effectiveness of discontinuities on rock mass behavior requires that the discontinuities in the quality such as discontinuity system or rock structure are explained [16]. Joint study in all parts of the rock mass show that the main discontinuities in the Bakhtiari dam diversion section consists of two set of discontinuities, bedding, a major joint (J1), and also random joints (faults and fractures).

Characteristics of discontinuities have been studied during the drilling of the tunnel (underground). The dip and dip directions of the discontinuities are presented in Table 2, and specifications of the bedding and J1 joint system are presented in Table 3.

\subsection{Rock Mass}

3.3.1. Classification. Engineering classification of rock masses is presented in various ways by different researchers and has been used for designing tunnel supports by many researchers [17-20]. The main aims of application of rockmass classification systems are to classify the rock masses existing at a project site, based on their main geotechnical feature and to estimate the geotechnical parameters of the rock masses. The role of classification is generally to get a better overview of a phenomenon or set of data in order to understand them or to take different actions concerning them [21]. In this regard, simple techniques are used for quantitative evaluation of a number of the main geotechnical features of the rock masses and then the rock masses are classified based on these classification systems.

In order to classify the rock masses in the Bakhtiari dam diversion tunnel, the rock-mass quality-index method (RQD), geomechanical rock-mass rating (RMR) and rock mass classification of tunnels containing the $Q$ system are used.

3.3.2. Rock-Mass Quality Index (RQD). Rock-mass quality index can be measured through direct core drilling or indirect, in cases where there is no possibility of the core, such as seismic methods or volumetric counting joints. In the project area, geological structures such as the F1, F2, and F3 faults, the kink-band zones, the anticline-axis zone, the 
TABLE 3: Specification of the main discontinuities in diversion tunnel.

\begin{tabular}{|c|c|c|c|c|c|c|}
\hline \multirow[t]{2}{*}{ Discontinuity type } & \multicolumn{2}{|c|}{ Roughness } & \multicolumn{2}{|c|}{ Filling } & \multicolumn{2}{|c|}{ Spacing $(\mathrm{mm})$} \\
\hline & Rough (R) & $34 \%$ & Clean & $10 \%$ & $\leq 1$ & $45 \%$ \\
\hline \multirow{5}{*}{ Bedding } & Smooth $(\mathrm{Sm})$ & $35 \%$ & Calcite-clay & $29 \%$ & $1-5$ & $42 \%$ \\
\hline & Slicken Slid (Sl) & $26 \%$ & Calcite & $36 \%$ & $5-10$ & $8 \%$ \\
\hline & Diverse & $5 \%$ & Clay & $20 \%$ & $10-50$ & $5 \%$ \\
\hline & - & 一 & Diverse & $5 \%$ & Diverse & $0 \%$ \\
\hline & Total & $100 \%$ & Total & $100 \%$ & Total & $100 \%$ \\
\hline \multirow{6}{*}{ Main joint (J1) } & Rough (R) & $86 \%$ & Clean & $5 \%$ & $\leq 1$ & $4 \%$ \\
\hline & Smooth (Sm) & $5 \%$ & Calcite-clay & $6 \%$ & $1-5$ & $46 \%$ \\
\hline & $\mathrm{R}-\mathrm{Sm}$ & $5 \%$ & Calcite & $70 \%$ & $5-10$ & $5 \%$ \\
\hline & Slicken slid (Sl) & $4 \%$ & Clay & $14 \%$ & $10-50$ & $4 \%$ \\
\hline & Diverse & $0 \%$ & Iron oxide & $5 \%$ & $>50$ & $0 \%$ \\
\hline & Total & $100 \%$ & Total & $100 \%$ & Total & $100 \%$ \\
\hline
\end{tabular}

TABLE 4: Ranges of RQD values and description of the five definite rock-mass classes [1].

\begin{tabular}{lccccr}
\hline RQD & $0-25$ & $25-50$ & $50-75$ & $75-90$ & $90-100$ \\
\hline Description & Very poor & Poor & Fair & Good & Excellent \\
\hline
\end{tabular}

TABle 5: Profile of rock-mass classification in different geological zones of upper diversion tunnel.

\begin{tabular}{lcccccccccc}
\hline Rock unit & SV2 & SV3 & SV3 Dis & SV2 and SV3 & SV4 & SV5 & SV6 & SV5 and SV6 Dis & SV7 & F2 fault zone \\
\hline RQD & 80 & 80 & 75 & 75 & 80 & 95 & 80 & 75 & 90 & 65 \\
Description & Good & Good & Good & Good & Good & Excellent & Good & Good & Good & Fair \\
\hline
\end{tabular}

TABLE 6: Range of RMR values and description of the rock-mass class [5].

\begin{tabular}{lccccc}
\hline RMR & $81-100$ & $61-80$ & $41-60$ & $21-40$ & IV \\
\hline Rock-mass class & I & II & III & V \\
Description & Very good & Good & Fair & Poor & Very poor \\
\hline
\end{tabular}

TABLE 7: Results of RMR classification and final results of RMR classification of rock masses along Bakhtiari upper diversion tunnel [5].

\begin{tabular}{lcccccccccc}
\hline Rock units & SV2 & SV3 & SV3 dis & SV2 and SV3 & SV4 & SV5 & SV6 & SV5 and SV6 dis & SV7 & F2 fault zone \\
\hline RMR & 75 & 77 & 68 & 61 & 80 & 95 & 77 & 61 & 75 & 61 \\
Description & Good & Good & Good & Good & Good & Very Good & Good & Good & Good & Good \\
Rock mass class & II & II & II & II & II & I & II & II & II & II \\
\hline
\end{tabular}

joint sets, and in some cases the lithological bedding planes have a remarkable effect on the RQD value.

According to this method, the numerical quality-index values corresponding to each part of the rock masses of the Bakhtiari dam tunnel has been done. In order to determine the numerical values of rock mass quality index from the volumetric joint count method in the surface outcrops and the tunnel space, that proposed by Palmstrom was used [2225]. Under this method, small amounts of this parameter are measured in accordance with the following equation:

$$
\mathrm{RQD}=110-2.2 \mathrm{JV}
$$

In this regard, the JV is the total number of discontinuities in rock mass per unit volume. Based on RQD values five definite rock-mass classes are described (Table 4) [1]. RQD values in all zones have been calculated and their descriptions are presented in Table 5 .

3.3.3. Geomechanical Rock-Mass Rating (RMR). RMR is one of the various methods in geomechanic rating [26]. Geomechanical rock mass rating (RMR) was introduced in scientific research and industrial (CSIR) in South Africa by Bieniawski [27]. It was based on his experiences in shallow tunnels in sedimentary rocks. 
TABLE 8: Ranges of $Q$ values and description of the rock-mass classes.

\begin{tabular}{lcl}
\hline$Q$ & Rock-mass class & Description \\
\hline $1000-400$ & & Exceptionally good \\
$400-100$ & I & Extremely good \\
$100-40$ & & Very good \\
$40-10$ & & Good \\
\hline $10-4$ & & Fair \\
$4-1$ & II & Poor \\
$1-0.1$ & & Very poor \\
\hline $0.1-0.01$ & & Extremely poor \\
$0.01-0.001$ & III & Exceptionally poor \\
\hline
\end{tabular}

All the rock units along the diversion tunnels have been classified using RMR system proposed by Bieniawski [5]. In Table 6, ranges of RMR values for the five definite rock-mass classes along with their description as suggested by Bieniawski [5] are shown. The final results of RMR classification of the rock masses along the upper diversion tunnel together with their description are presented in Table 8. As it is shown in Table 7, different rock units along the upper diversion tunnel are classified using RMR system, have good to very good Quality.

3.3.4. Rock-Mass Quality (Q). Rock-mass quality $(Q)$ system that was developed by Barton et al. [1], mainly for tunneling has been proposed. In this classification system, the $Q$ values of the rock masses along the tunnels are evaluated based on six parameters, and the required support system is specified for each rock mass $[10,17]$. The $Q$ system is developed as an empirical design method for estimating rock support [28]. The ranges of $Q$ values are illustrated in Table 8. Accordingly, the $Q$ values for the rock masses of different geological units along the di version tunnels are presented in Table 9. Based on Tables 8 and 9, all rock units have good quality in the $Q$ classification.

3.4. Rock-Support Design Based on Empirical Methods. Empirical methods have been developed based on the statistical analysis of the records on the stability and also instability of underground excavations performed in different types of rock masses in several countries. The two most widely used engineering rock-mass classification systems for estimating rock support system of underground openings are "Rock Mass Rating" (RMR) and "Rock-Mass Quality" $(Q)$. These classification systems have been applied for categorizing the rock masses along the diversion tunnels.

As the first step of rock support design for the diversion tunnels at Bakhtiari project site, having the results of rockmass classifications by the two above mentioned systems, the rock-support measures relevant to each rock mass class have been estimated and proposed in the following sections.

3.5. Estimation of Rock-Support System Based on RMR. The required rock-support systems for the upper diversion tunnel were estimated considering the RMR values attributed to the rock masses along these tunnels, as presented in Table 8 . A guideline proposed by Bieniawski [5] for selection of the tunnel rock-support measures when they are excavated in one of the five main rock-mass classes of RMR system. The estimated rock-support systems for the diversion tunnels are presented in Table 10.

3.6. Estimation of Rock-Support System Based on Q. In order to estimate the required rock support system for an underground opening based on the $Q$ support chart, the diameter or height $(\mathrm{m})$ of excavation span shall be converted to "Excavation equivalent dimension" (De). In this regard, real diameter should be corrected by dividing it to a parameter called as "Excavation Support Ratio" (ESR) which is related to the intended use of the excavation and degree of security which is demanded of the support system installed to maintain the stability of the excavation.

Excavation equivalent dimension, De (m)

$$
=\frac{\text { Diameter or height of the excavation span }(\mathrm{m})}{\text { ESR }}
$$

The relevant ESR value for the diversion tunnel was taken as 1.6, according to Barton et al. [1]. Excavation diameter of the upper diversion tunnels is $13.7 \mathrm{~m}$. Having De and Qvalues for different types of rock masses along the diversion tunnels, the required rock support measures for the different rock masses were estimated based on the Q-support chart proposed by Grimstad and Barton [10] as shown in Figure 3. The results of estimation of the required rock support system for the diversion tunnel are presented in Table 11.

\section{Summary and Conclusion}

Based on studies conducted during the drilling upper di version tunnel of Bakhtiari dam, was found that:

(i) The upper di version tunnels of the Bakhtiari dam passes through seven different geological zones (SV1 to SV7 and F2 fault zone) that mainly have consisted of carbonate deposits of Sarvak formation from Bangestan group.

(ii) Much of these parts are formed of marly limestone with different thicknesses that sometimes have been associated with the shale layers. SV4 and SV5 parts were formed of the thick limestone layer with nodules mainly made of siliceous limestone and rarely chert.

(iii) Based on joint studies, there are two main discontinuities including bedding and major joint (J1) associated with random joint (faults and fractures).

(iv) About 45 percent of the discontinuities have $1 \mathrm{~mm}$ spacing, and 42 percent of them show $5-1 \mathrm{~mm}$ spacing and almost all of them have been filled mainly by calcite or calcite and clay.

(v) According to the rock-mass classification methods (especially methods of RMR and Q), the rock masses 
TABLE 9: $Q$ values for rock masses of different geological units along Bakhtiari diversion tunnel.

\begin{tabular}{lcccccccccc}
\hline Rock units & SV2 & SV3 & SV3 Dis & SV2 and SV3 & SV4 & SV5 & SV6 & SV5 and SV6 Dis & SV7 & F2 fault zone \\
\hline Q & 14 & 15 & 11 & 10 & 15 & 35 & 14 & 11 & 12 & 10 \\
Description & Good & Good & Good & Good & Good & Good & Good & Good & Good & Good \\
\hline
\end{tabular}

TABLE 10: Estimation of rock support system for the upper diversion tunnel.

\begin{tabular}{lcclll}
\hline $\begin{array}{l}\text { Rock masses of different } \\
\text { geological units }\end{array}$ & RMR & Rock-mass class & $\begin{array}{l}\text { Proposed } \\
\text { Fully grouted rock bolt }(\Phi 20 \mathrm{~mm})\end{array}$ & Rock Shocrete & $\begin{array}{l}\text { Support } \\
\text { Steel Rib }\end{array}$ \\
\hline SV2 & 75 & II & $3 \mathrm{~m}$ rock bolts in crown at $2.5 \mathrm{~m}$ spacing & $50 \mathrm{~mm}$ in crown & No need \\
SV3 & 77 & II & 3 m rock bolts in crown at $2.5 \mathrm{~m}$ spacing & $50 \mathrm{~mm}$ in crown & No need \\
SV3 Dis & 68 & II & $3 \mathrm{~m}$ rock bolts in crown at $2.5 \mathrm{~m}$ spacing & $50 \mathrm{~mm}$ in crown & No need \\
SV2 and SV3 & 61 & II & $3 \mathrm{~m}$ rock bolts in crown at $2.5 \mathrm{~m}$ spacing & $50 \mathrm{~mm}$ in crown & No need \\
SV4 & 80 & II & $3 \mathrm{~m}$ rock bolts in crown at $2.5 \mathrm{~m}$ spacing & $50 \mathrm{~mm}$ in crown & No need \\
SV5 & 95 & I & Local bolting & No need & No need \\
SV6 & 77 & II & $3 \mathrm{~m}$ rock bolts in crown at $2.5 \mathrm{~m}$ spacing & $50 \mathrm{~mm}$ in crown & No need \\
SV5 and SV6 Dis & 61 & II & $3 \mathrm{~m}$ rock bolts in crown at $2.5 \mathrm{~m}$ spacing & $50 \mathrm{~mm}$ in crown & No need \\
SV7 & 75 & II & $3 \mathrm{~m}$ rock bolts in crown at $2.5 \mathrm{~m}$ spacing & $50 \mathrm{~mm}$ in crown & No need \\
F2 fault zone & 61 & II & $3 \mathrm{~m}$ rock bolts in crown at $2.5 \mathrm{~m}$ spacing & $50 \mathrm{~mm}$ in crown & No need \\
\hline
\end{tabular}

TABLE 11: Estimation of the rock-support systems for the upper diversion tunnel based on Q-support chart [10].

\begin{tabular}{|c|c|c|c|c|}
\hline $\begin{array}{l}\text { Rock masses of different geological } \\
\text { units }\end{array}$ & $Q$ & $\begin{array}{l}\text { Proposed } \\
\text { untensioned rock } \\
\text { bolt (fully grouted) }\end{array}$ & $\begin{array}{l}\text { Rock } \\
\text { Shotcrete }\end{array}$ & $\begin{array}{l}\text { Support } \\
\text { Steel Rib }\end{array}$ \\
\hline SV2 & 14 & $3 \mathrm{~m}$ rock bolts at $2.4 \mathrm{~m}$ spacing & Systematic bolting & No need \\
\hline SV3 & 15 & $3 \mathrm{~m}$ rock bolts at $2.4 \mathrm{~m}$ spacing & Systematic bolting & No need \\
\hline SV3 Dis & 11 & $3 \mathrm{~m}$ rock bolts at $2.3 \mathrm{~m}$ spacing & $\begin{array}{l}\text { Systematic bolting with } 40 \mathrm{~mm} \\
\text { unreinforced shotcrete }\end{array}$ & No need \\
\hline SV2 and SV3 & 10 & $3 \mathrm{~m}$ rock bolts at $2.3 \mathrm{~m}$ spacing & $\begin{array}{l}\text { Systematic bolting with } 40 \mathrm{~mm} \\
\text { unreinforced shotcrete }\end{array}$ & No need \\
\hline SV4 & 15 & $3 \mathrm{~m}$ rock bolts at $2.4 \mathrm{~m}$ spacing & Systematic bolting & No need \\
\hline SV5 & 35 & $3 \mathrm{~m}$ rock bolts at $3 \mathrm{~m}$ spacing & Spot bolting & \\
\hline SV6 & 14 & $3 \mathrm{~m}$ rock bolts at $2.4 \mathrm{~m}$ spacing & Systematic bolting & No need \\
\hline SV5 and SV6 Dis & 11 & $3 \mathrm{~m}$ rock bolts at $2.3 \mathrm{~m}$ spacing & $\begin{array}{l}\text { Systematic bolting with } 40 \mathrm{~mm} \\
\text { unreinforced shotcrete }\end{array}$ & No need \\
\hline SV7 & 12 & $3 \mathrm{~m}$ rock bolts at $2.3 \mathrm{~m}$ spacing & $\begin{array}{l}\text { Systematic bolting with } 40 \mathrm{~mm} \\
\text { unreinforced shotcrete }\end{array}$ & No need \\
\hline F2 fault zone & 10 & $3 \mathrm{~m}$ rock bolts at $2.3 \mathrm{~m}$ spacing & $\begin{array}{l}\text { Systematic bolting with } 40 \mathrm{~mm} \\
\text { unreinforced shotcrete }\end{array}$ & No need \\
\hline
\end{tabular}

in diversion tunnel have been in the good to very good quality category.

(vi) Based on RQD all unites show 75 to 90 value range (except F2 fault zone with 61 values) and good to excellent quality.

(vii) In both (RMR and $Q$ ) systems most of the rock units hosting the tunnel fall into good to very good class. (viii) According to RMR method, $3 \mathrm{~m}$ rock bolts in crown, $2.5 \mathrm{~m}$ spacing and with $50 \mathrm{~mm}$ shotcrete in crown has been proposed.

(ix) Based on Q method, 2.3-2.4 m spacing with Systematic Bolting without shotcrete or $40 \mathrm{~mm}$ unreinforced shotcrete in some units has been proposed.

(x) For SV5 zone with very good and excellent quality, local bolting without shotcrete according to RMR-method and $3 \mathrm{~m}$ rock bolts, $3 \mathrm{~m}$ spacing and 
spot bolting according to $Q$ method has been proposed.

\section{References}

[1] N. Barton, R. Lien, and J. Lunde, "Engineering classification of rock masses for the design of tunnel support," Rock Mechanics Felsmechanik Mécanique des Roches, vol. 6, no. 4, pp. 189-236, 1974.

[2] E. Hoek, "Rock Enginnering," Course Notes, 2007.

[3] E. Hoek and P. Marinos, "Predicting tunnel squeezing problem in weak heterogeneous rock masses," Tunnels and Tunnelling international, Part1, November 2000, Part2, December 2000.

[4] B. Singh and R. K. Geol, Tunnelling in Weak Rock, vol. 5 of Elsevier Geo-Engineering Book Series, 2006.

[5] Z. T. Bieniawski, Engineering Rock Mass Classifications, John Wiley and Sons, New York, NY, USA, 1989.

[6] T. Miranda, A. Gomes Correia, I. Nogueira, M. Santos, P. Cortez, and L. Ribeiro e Sousa, "Alternative models for the calculation of the RMR and Q indexes for granite rock masses," in Proceedings of the 5th International Workshop on Application of Computational Methods in Geotechnical Engineering, R. Sousa, M. M. Fernandes, E. Vargas Jr., and R. Azevedo, Eds., pp. 151-162, Taylor \& Francis Group, Guimarães, Portugal, April 2007.

[7] B. Sing and R. k. Goel, Rock Mass Classification, University of Roorke India, 1999.

[8] K. Rajnish and S. G. Bhawani, Tunneling in Weak Rocks, Elsevier Geo-Engineering Book Series, 2006.

[9] S. M. Hossaini, F. Nezhadshahmohamad, and M. Dadkhah, "Stability assessment and support design for water deviation binary tunnels of bakhtiyari dam-Iran," in Proceedings of the 11th Underground Coal Operators' Conference, University of Wollongong Research Online, 2011.

[10] E. Grimstad and N. Barton, "Updating the Q-System for NMT," in Proceedings of the International Symposium on Sprayed Concrete-Modern Use of Wet Mix Sprayed Concrete for Underground Support, Fagernes, pp. 46-66, Norwegian Concrete Association, Oslo, Norway, 1993.

[11] Iran Water and Power Resourced Development Co, "Geological report of bakhtiari dam," 2006.

[12] K. R. Davis, "The geology of an area in southest Lurestan, GR1104," 1964.

[13] Iran Water and Power Resourced Development Co, "In-situ and laboratory rock mechanics tests of Bakhtiari Dam," 2008.

[14] Anon, "Classification of rocks and soils for engineering geological mapping," Bulletin of the International Association of Engineering Geology, no. 19, pp. 364-371, 1979.

[15] N. R. Barton, "Predicting the behavior of underground opening in rock," Manuel Rocha Memorial Lecture, Lisbon, Norwegian Geotechnical Institute, Oslo, Norway, 1978.

[16] D. Saiang, "Stability analysis of the blast-induced damage zone by continuum and coupled continuum-discontinuum methods," Engineering Geology, vol. 116, no. 1-2, pp. 1-11, 2010.

[17] N. Barton, "Some new Q-value correlations to assist in site characterisation and tunnel design," International Journal of Rock Mechanics and Mining Sciences, vol. 39, no. 2, pp. 185216, 2002.

[18] T. Ramamurthy, "A geo-engineering classification for rocks and rock masses," International Journal of Rock Mechanics and Mining Sciences, vol. 41, no. 1, pp. 89-101, 2004.

[19] E. Hoek and M. S. Diederichs, "Empirical estimation of rock mass modulus," International Journal of Rock Mechanics and Mining Sciences, vol. 43, no. 2, pp. 203-215, 2006.

[20] Z. Gurocak, P. Solanki, and M. M. Zaman, "Empirical and numerical analyses of support requirements for a diversion tunnel at the Boztepe dam site, eastern Turkey," Engineering Geology, vol. 91, no. 2-4, pp. 194-208, 2007.

[21] H. Stille and A. Palmström, "Classification as a tool in rock engineering," Tunnelling and Underground Space Technology, vol. 18, no. 4, pp. 331-345, 2003.

[22] A. Palmström and R. Singh, "The deformation modulus of rock masses-comparisons between in situ tests and indirect estimates," Tunnelling and Underground Space Technology, vol. 16, no. 2, pp. 115-131, 2001.

[23] A. Palmstrøm, "Characterizing rock masses by the RMi for Use in Practical Rock Engineering: Part 1: The development of the Rock Mass index (RMi)," Tunnelling and Underground Space Technology, vol. 11, no. 2, pp. 175-188, 1996.

[24] A. Palmstrom, RMI-A rock mass classification system for rock engineering purposes [Ph.D. thesis], University of Oslo, 1995.

[25] A. Palmstorm, "The volumetric joint count- a useful and simple neasure of the degree of rock jointing," in Proceedings of the 4th Congress of the International Association of Engineering Geology, vol. 5, pp. 221-228, New Delhi, India, 1985.

[26] H. Katibeh and A. Aalianvari, "Development of a new method for tunnel site rating from groundwater hazard point of view," Journal of Applied Sciences, vol. 9, no. 8, pp. 1496-1502, 2009.

[27] Z. T. Bieniawski, Rock Mechanics Design in Mining and Tunneling, A. A. Balkema publishing Co, 1984.

[28] A. Palmstrom, "Combining the RMR, Q, and RMi classification systems," 25p, 1996, http://www.rockmass.net/. 

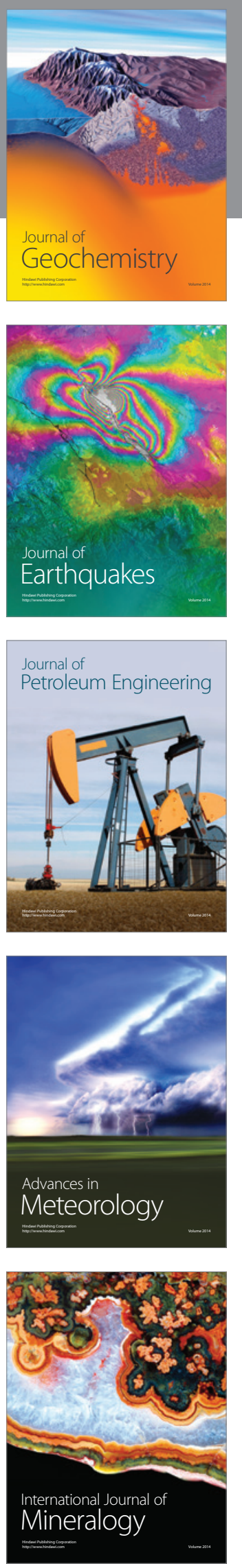
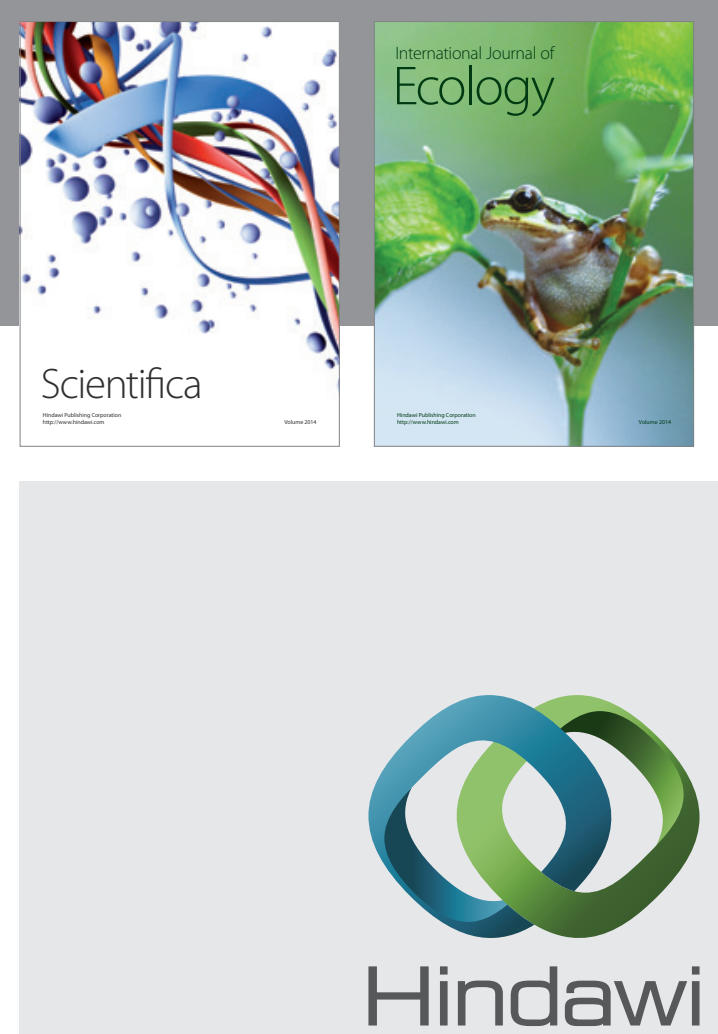

Submit your manuscripts at http://www.hindawi.com
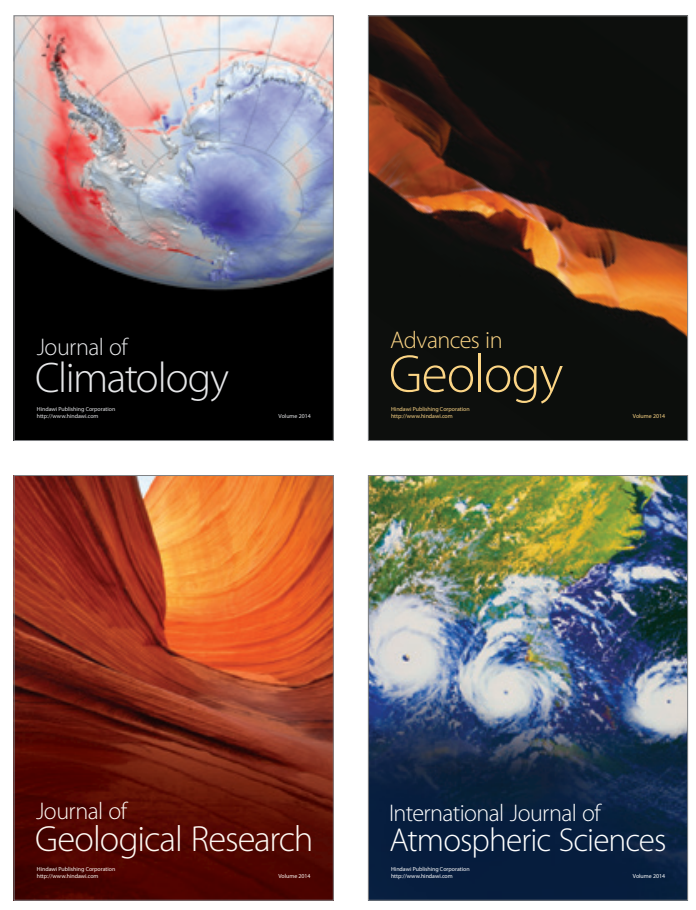
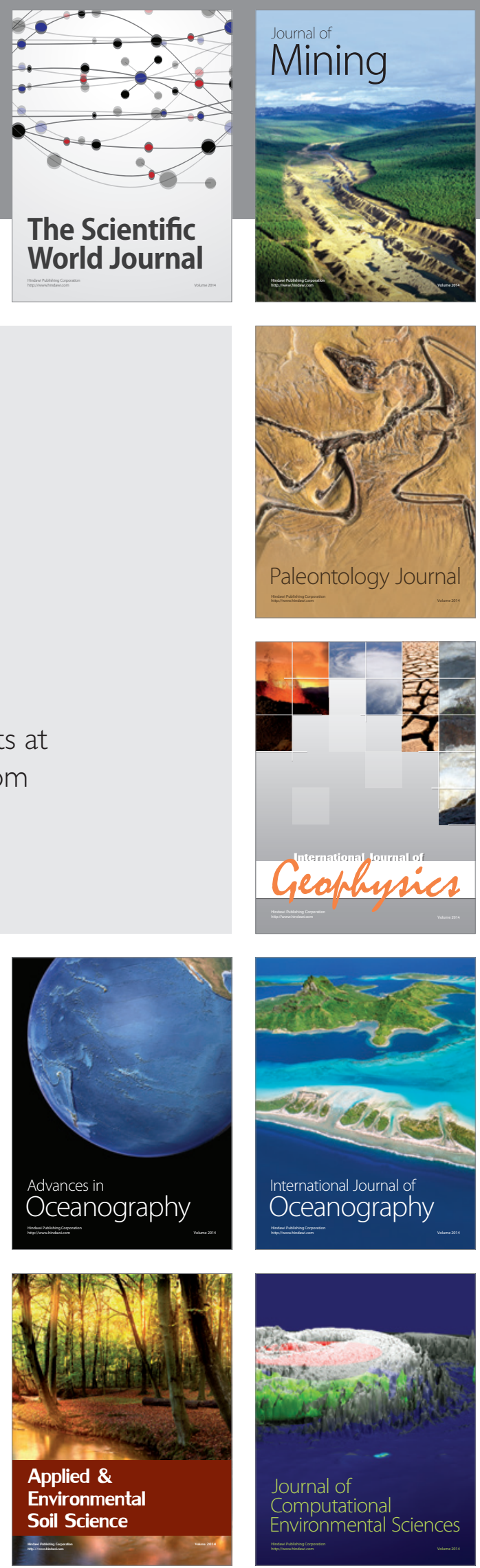